\title{
ABeta amyloidosis, Italian type
}

INSERM

\section{Source}

INSERM. (1999). Orphanet: an online rare disease and orphan drug data base. ABeta amyloidosis, Italian type. ORPHA:324713

Hereditary cerebral hemorrhage with amyloidosis (HCHWA), Italian type is a form of HCHWA (see this term) characterized by an age of onset of 50 years of age, dementia and lobar intracerebral hemorrhage. 